\title{
Institutional Translation and Interpreting
}

Assessing Practices and Managing for Quality

\section{Edited by \\ Fernando Prieto Ramos}

First published 2020

ISBN: 978-0-367-21023-6 (hbk)

ISBN: 978-0-429-26489-4 (ebk)

\section{Chapter 7}

Ensuring Consistency and Accuracy of Legal Terms in Institutional Translation

The Role of Terminological Resources in International Organizations

Fernando Prieto Ramos

CC BY-NC-ND 4.0

The OA chapter is funded by the Universite de Gèneve 


\section{Ensuring Consistency and Accuracy of Legal Terms in Institutional Translation}

The Role of Terminological

Resources in International

Organizations

\section{Fernando Prieto Ramos}

\subsection{Introduction}

The consistency and accuracy of terminology are central aspects of translation quality and, therefore, key aims of translation-oriented terminology management. For any given context, except for terms that can be considered interchangeable, terminological accuracy is expected to imply a high degree of consistency within the same text and, as far as possible, with other occurrences of the same term in texts that are directly relevant to the translation at hand, especially for the same purposes and users. Accordingly, terminological consistency can be viewed as both an intratextual requirement and an intertextual aspiration. By the same token, high levels of inconsistency for the same concept in a comparable translation context will usually imply some risk of semantic deviation among renderings of the same original term.

It is no coincidence that terminological consistency and semantic accuracy are the first two requirements established for the translation process in the quality standard ISO 17100:2015: “a) compliance with specific domain and client terminology and/or any other reference material provided and ensuring terminological consistency during translation; b) semantic accuracy of the target language content" (ISO 2015, 10). Despite the relevance of these quality requirements, the two main challenges highlighted with regard to terminology management in a survey recently conducted by the International Network for Terminology (TermNet) among practitioners in this field were the lack of awareness of the importance of terminology management and the consistency of terminology, according to $57.65 \%$ and $56.47 \%$ of 86 participants, respectively. These challenges were followed by the lack of time $(45.88 \%)$ and human resources $(43.53 \%)$ for terminology management. ${ }^{1}$

In the case of texts translated in international organizations, interlinguistic concordance and intralinguistic consistency are essential requirements of institutional translation for the sake of semantic univocity (e.g.

DOI: $10.4324 / 9780429264894-10$ 
Prieto Ramos 2014a, 314; Robertson 2015, 41; Stefaniak 2017, 116). This is particularly sensitive in the process of producing multilingual texts that establish, implement or provide information about rights, conditions or obligations. As expressed by Stefaniak $(2017,117)$ with regard to translation in the European Commission, consistency "is often more important than any other criterion" in translation decisionmaking; "[v]arious translations of the same term, especially in legal acts, may mislead the reader to think that these terms denote different concepts and make it difficult to interpret legislation" (ibid., 116). In other words, terminological consistency is also a matter of uniform interpretation and legal certainty (see, e.g., Šarčević 2013). De Saint Robert also refers to consistency or "continuity in a text" as a key aspect of translation quality assessment at the United Nations (UN), and links the assessment of terminological accuracy to consistency "in the use of terms in the database" $(2009,388)$.

The connection between institutional translation decisions and terminological databases is only logical considering the function of these resources at international organizations. They constitute priority resources for the verification of terminology, and de facto authoritative sources in the case of terms established for institution-specific notions or processes in particular. As they are developed for the highly repetitive and predictable contexts of institutional drafting, they can expedite terminological research and play a vital role in ensuring consistency and accuracy across translation services. This role may be more efficient and practical when the terminological problems are complex and time-consuming for translators. This often applies to legal terms that originated in specific legal traditions and are used in texts translated for international organizations, for example, in reports on the implementation of international legal instruments at national level.

Despite the remarkable development of institutional terminological resources (abbreviated here as "ITRs"), previous research shows that consistency and accuracy issues can be significant in both institutional translation patterns and terminological database records for certain legal terms (see Section 7.2). This study will explore these issues further using quantitative and qualitative analyses of translations of three illustrative legal terms in multilingual documents and ITRs at the European Union (EU) institutions, the UN and the World Trade Organization (WTO). These analyses have been produced by a more extensive research project on legal translation practices at these institutions. ${ }^{2}$

\subsection{Approach and Hypotheses}

As mentioned earlier, previous studies highlight the implications of inconsistencies and inaccuracies in legal terminological decisions within institutional translations, e.g. trade law terms in EU directives (Šarčević 
2010, 31-32) and national court names in texts of international organizations (Prieto Ramos 2013, 98-102). The latter study revealed that approximately two thirds of the translations of "magistrates' court" into Spanish reproduced the false friend "tribunal de magistrados" in two major institutions as of October 2012 (ibid., 99). It also showed the inconsistencies found in available terminological resources, particularly bilingual dictionaries. Similar shortcomings, from the perspective of translation-oriented legal lexicographical needs, were also detected in institutional termbank entries on national courts dealing with criminal cases (Prieto Ramos 2014b).

This study builds on the same preliminary analyses and adopts the approach of the LETRINT project in distinguishing between multilingual terminology established at international organizations to designate concepts within the realm of their recognized competences (e.g. human rights treaties at the UN or international trade rules at the WTO) and other terminology coined outside international organizations and used (a) to refer to concepts with generally shared meanings in multiple jurisdictions (e.g. "compliance", "appeal", "evidence") or (b) to designate concepts more specific to certain traditions or jurisdictions (e.g. singular proceedings, entities or legal provisions).

The use of the first group of well-established terminology in institutional translations is expected to be highly consistent, and also influential in the domains of recognized competence of the relevant organizations. However, consistency and accuracy levels are generally less predictable for the other groups of legal terminology. It is presumed that higher degrees of singularity or asymmetry (between the legal traditions associated with the original term and the target language) call for advanced translation competence and represent more significant challenges to consistency and accuracy in institutional translation settings. This may be compounded by the fact that these terms are usually less of a priority for institutional terminology management.

A potential correlation between consistency and accuracy levels was observed in the Spanish translations of "due process" in the abovementioned institutional settings (Prieto Ramos and Guzmán 2018). Interestingly, the setting with the highest levels of consistency and accuracy, the WTO, also showed the most marked degree of adherence to terminological recommendations in an internal glossary (93.74\% of occurrences), whereas the EU registered the lowest rates for both indicators and only $22.58 \%$ of adherence to IATE (Interactive Terminology for Europe) recommendations for the term. While the EU subcorpus was smaller than those of the UN and the WTO, the results raise questions about the difficulties in identifying legal terminological nuances and the use of ITRs for the translation of this kind of terminology.

The lexicometric analyses presented below were also conducted in the framework of the LETRINT project in order to test the earlier hypotheses 
at a larger scale. More specifically, we examine the connections between the levels of legal singularity of terms (and their associated difficulty for translation from English to Spanish) and the degrees of consistency and accuracy of their renderings. Three terms were selected for the following reasons: (1) they are considered representative of groups of terms with varying degrees of legal singularity or asymmetry for translation, as identified in the LETRINT corpora, (2) they are illustrative of recurrent semantic fields within these groups and (3) they occur with sufficient frequency in the three institutional settings for comparative analysis. The three terms are:

- "prima facie evidence" (abbreviated as "PFE"): an example of procedural legal terminology adopted at international organizations through the influence of the common law tradition ${ }^{3}$ and with closely corresponding prima facie standards in civil law systems such as the Spanish-speaking jurisdictions, i.e. the legal singularity is relatively limited but several renderings are possible in Spanish (for example, "prueba prima facie" or "prueba indiciaria", also found in national laws), and some previous legal knowledge or verifications are required for translation decision-making;

- "tort": a concept unique to common law that requires a descriptive or partially functional reformulation in Spanish to convey the idea of civil wrong (e.g. "ilícito civil extracontractual") or the legal liability resulting from it (e.g. "responsabilidad extracontractual"), i.e. the significant legal singularity of the term calls for specific attention and comparative legal analysis;

- "magistrates' court" (abbreviated as "MC"): a court name that illustrates system-specific denominations of judicial entities and entails not only a high degree of asymmetry with target-language judicial systems but also a risk of misleading rendering in Spanish due to the false friend "magistrado" (a senior judge, as opposed to "magistrate").

The level of translation difficulty may be perceived differently depending on the translator's previous specialization. Overall, however, it is presumed that the meaning of the first term will be easier to grasp and convey than the other two common law concepts. Advanced competence in legal translation will be critical in detecting these difficulties and making appropriate and efficient translation decisions. The role of terminological resources can be particularly helpful to compensate for specialization gaps in this context. In turn, this strengthens the relevance of observing translation patterns and ITR recommendations for varying levels of legal singularity or asymmetry.

The corpora compiled for the study include all occurrences of the selected terms in English, and their translations into Spanish, in documents 


\section{Fernando Prieto Ramos}

published in 2005-2015 and 2016-2019, and retrieved from the following institutional repositories: the EU's EUR-Lex portal, the UN's Official Document System (ODS) and the WTO's Documents Online database. In order to draw a comprehensive overview of recent practices, the corpora comprise three years over a decade (2005, 2010 and 2015) and the subsequent four years (2016-2019). This provides perspective for examining the consistency of decisions over a considerable time span, including patterns of translation precedents and the potential impact of ITR changes or of the increasing automation in translation workflows witnessed in recent years.

After the analyses of consistency and accuracy of translations (Section 7.3), their congruity with ITR recommendations will be examined more closely, with a particular focus on the potential role of these resources in the most statistically significant patterns of terminological decision-making identified (Section 7.4). More methodological details are provided in each section.

\subsection{Analysis of Consistency and Accuracy Indicators}

\subsubsection{Overall Translation Variability}

The initial search query results (including singular and plural forms) were screened in order to exclude occurrences that did not refer to the concepts selected for the study, for example, longer terms that deviate from the original concepts or translations of court names from languages other than English (e.g. "administrative tort" or "Federal Magistrates Court"). Table 7.1 shows the total number of occurrences that qualified for analysis and the number of documents from which they were extracted per period and institutional setting. A total of 1,038 occurrences of Spanish renderings of the English terms from 606 documents were considered for the analysis of translation consistency and accuracy. Multiple instances of each term were found in each period and translation setting, except for "magistrates' court", which registered a single occurrence in EU texts compiled for 2016-2019.

The most recurrent textual functions of the documents are related to policy implementation or monitoring at the supranational or national levels, in the areas of trade and judicial cooperation in the EU, human rights at the UN and trade at the WTO. The most frequently used term is "PFE". It was found in the widest range of text types in all the organizations, including EU legal instruments, UN reports and WTO trade policy review and dispute settlement documents. This reflects the widespread adoption of the concept in international jurisdictions, as opposed to more system-specific terms. The largest and most homogeneous subset of documents or "system of genres" (Bazerman 1994, 97), as regards theme, legal framework and genre conventions, is composed of EU texts 
Table 7.1 Number of occurrences analyzed (and corresponding number of documents)

\begin{tabular}{|c|c|c|c|c|c|}
\hline & & PFE & tort & $M C$ & Total \\
\hline \multirow[t]{3}{*}{ EU } & $\begin{array}{l}\text { No. of occurrences (docs) } \\
\quad(2005-2015)\end{array}$ & $273(166)$ & $12(10)$ & $20(7)$ & $305(183)$ \\
\hline & $\begin{array}{l}\text { No. of occurrences (docs) } \\
(2016-2019)\end{array}$ & $170(96)$ & $60(14)$ & $1(1)$ & $231(111)$ \\
\hline & Total occurrences (docs) & $443(262)$ & $72(24)$ & $21(8)$ & $536(294)$ \\
\hline \multirow[t]{3}{*}{ UN } & $\begin{array}{l}\text { No. of occurrences (docs) } \\
\quad(2005-2015)\end{array}$ & $54(42)$ & $22(15)$ & $62(37)$ & $138(94)$ \\
\hline & $\begin{array}{l}\text { No. of occurrences (docs) } \\
\quad(2016-2019)\end{array}$ & $75(48)$ & $68(43)$ & $40(23)$ & $183(114)$ \\
\hline & Total occurrences (docs) & $129(90)$ & $90(58)$ & $102(60)$ & $321(208)$ \\
\hline \multirow[t]{3}{*}{ WTO } & $\begin{array}{l}\text { No. of occurrences (docs) } \\
\quad(2005-2015)\end{array}$ & $80(36)$ & $12(6)$ & $19(14)$ & $111(56)$ \\
\hline & $\begin{array}{l}\text { No. of occurrences (docs) } \\
(2016-2019)\end{array}$ & $36(26)$ & $13(4)$ & $11(8)$ & $60(38)$ \\
\hline & $\underline{\text { Total occurrences (docs) }}$ & $116(62)$ & $25(10)$ & $30(22)$ & $171(94)$ \\
\hline \multicolumn{2}{|c|}{ TOTAL } & $688(424)$ & $197(92)$ & $153(90)$ & $1,038(606)$ \\
\hline
\end{tabular}

on trade defense containing "PFE" (approximately 93\% of all the EU corpus components for this term): regulations, implementing regulations, notices and decisions on antidumping, countervailing and safeguard measures. Interestingly, the EU trade defense procedures conform to WTO agreement provisions (and therefore their original terminology) also referred to in the corpus components of this organization. In the case of the most system-specific term, "MC", the name is employed in connection with 33 different national jurisdictions (where English is an official or de facto language of the courts) in documents of the multilateral system (UN and WTO), as opposed to the EU texts, where references to the United Kingdom (more precisely, England and Wales or Northern Ireland) prevail.

A list of translations grouped per lexical clusters is provided in the Annex, including 44 for "PFE", 31 for "tort" and 17 for "MC". If we consider the number of documents where the original terms are used, these figures represent average variability rates of one different rendering in every 15.64, 9 and 6.16 occurrences of "PFE", "MC" and "tort", respectively, or every $9.64,5.29$ and 2.88 documents. In other words, translations of "PFE" are generally more consistent than those of the other two terms. The difference is particularly marked in the EU corpus, with a translation variant of "PFE" in Spanish in every 12.48 documents on average, as opposed to a rate of 3.6 in the UN corpus (see Table 7.2). Only in this organization, the overall variability rate points to slightly 


\section{Fernando Prieto Ramos}

higher consistency in the translations of "MC" (one variant per four documents). By contrast, the translations of "tort" are the least consistent in all the settings.

Table 7.2 also shows the three most recurrent translations of each term per setting. The most common ones coincide in the case of "PFE" at the UN and the WTO ("prueba prima facie") and "tort" in EU and UN documents ("responsabilidad civil", with the same frequency as

Table 7.2 Three most recurrent translations (per number of documents and occurrences ${ }^{1}$ ) and total number of translation variants and documents per term and setting

\begin{tabular}{|c|c|c|c|}
\hline & $E U$ & $U N$ & WTO \\
\hline \multirow[t]{4}{*}{ PFE } & $\begin{array}{l}\text { indicio razonable: } 226 \\
(336) \\
\text { (in } 86.26 \% \text { of docs) }\end{array}$ & $\begin{array}{l}\text { prueba prima facie: } 45 \text { (58) } \\
\text { (in } 50 \% \text { of docs) }\end{array}$ & $\begin{array}{l}\text { prueba prima facie: } 39 \text { (81) } \\
\text { (in } 62.90 \% \text { of docs) }\end{array}$ \\
\hline & $\begin{array}{l}\text { indicio a primera vista: } \\
5(5)\end{array}$ & indicio razonable: 15 (18) & prueba de presunción: 5 (5) \\
\hline & $\begin{array}{l}\text { elemento de prueba a } \\
\text { primera vista: } 4(7)\end{array}$ & principio de prueba: 8 (9) & presunción: 4 (5) \\
\hline & $\begin{array}{l}\text { Total: } 21 \text { translations in } \\
262 \text { docs } \\
\text { (average: } 1 \text { per } 12.48 \text { docs) }\end{array}$ & $\begin{array}{l}\text { Total: } 25 \text { translations in } \\
\quad 90 \text { docs } \\
\text { (average: } 1 \text { per } 3.60 \text { docs) }\end{array}$ & $\begin{array}{l}\text { Total: } 14 \text { translations in } 62 \\
\quad \text { docs } \\
\text { (average: } 1 \text { per } 4.43 \text { docs) }\end{array}$ \\
\hline \multirow[t]{4}{*}{ tort } & $\begin{array}{l}\text { responsabilidad civil: } 8 \text { (10) } \\
\text { (in } 33.33 \% \text { of docs) }\end{array}$ & $\begin{array}{l}\text { responsabilidad civil: } 11 \text { (14) } \\
\text { (in } 18.97 \% \text { of docs) }\end{array}$ & $\begin{array}{l}\text { ilícito civil: } 2 \text { (10) } \\
\text { (in } 20 \% \text { of docs) }\end{array}$ \\
\hline & $\begin{array}{l}\text { responsabilidad } \\
\quad \text { extracontractual: } 6(15)\end{array}$ & $\begin{array}{l}\text { responsabilidad } \\
\quad \text { extracontractual: } 11(14)\end{array}$ & responsabilidad civil: 2 (4) \\
\hline & acto ilícito: 5 (19) & agravio: 7 (20) & delito: 2 (4) \\
\hline & $\begin{array}{l}\text { Total: } 16 \text { translations in } \\
24 \text { docs } \\
\text { (average: } 1 \text { per } 1.50 \text { docs) }\end{array}$ & $\begin{array}{l}\text { Total: } 21 \text { translations in } \\
\quad 58 \text { docs } \\
\text { (average: } 1 \text { per } 2.76 \text { docs) }\end{array}$ & $\begin{array}{l}\text { Total: } 8 \text { translations in } 10 \\
\quad \text { docs } \\
\text { (average: } 1 \text { per } 1.25 \text { docs) }\end{array}$ \\
\hline \multirow[t]{4}{*}{$\mathrm{MC}$} & $\begin{array}{l}\text { magistrates' court: } 4 \text { (16) } \\
\text { (in 50\% of docs) }\end{array}$ & $\begin{array}{l}\text { tribunal de primera } \\
\text { instancia: } 28(47) \\
\text { (in } 46.67 \% \text { of docs) }\end{array}$ & $\begin{array}{l}\text { tribunal de magistrados: } \\
11(15) \\
\text { (in } 50 \% \text { of docs) }\end{array}$ \\
\hline & $\begin{array}{l}\text { tribunal de magistrados: } \\
3(3)\end{array}$ & $\begin{array}{l}\text { tribunal de magistrados: } \\
11(16)\end{array}$ & $\begin{array}{l}\text { corte de los magistrados: } \\
4(5)\end{array}$ \\
\hline & $\begin{array}{l}\text { Tribunal de Magistrados } \\
\text { (Magistrates' Court): } 1 \text { (1) }\end{array}$ & juzgado de paz: 6 (13) & juzgado de paz: 3 (4) \\
\hline & $\begin{array}{l}\text { Total: } 3 \text { translations in } 8 \\
\quad \text { docs } \\
\text { (average: } 1 \text { per } 2.67 \text { docs) }\end{array}$ & $\begin{array}{l}\text { Total: } 15 \text { translations in } \\
\quad 60 \text { docs } \\
\text { (average: } 1 \text { per } 4 \text { docs) }\end{array}$ & $\begin{array}{l}\text { Total: } 8 \text { translations in } 22 \\
\quad \text { docs } \\
\text { (average: } 1 \text { per } 2.75 \text { docs) }\end{array}$ \\
\hline
\end{tabular}

1 For each translation, the number of documents is followed by the number of total occurrences between brackets. 
"responsabilidad extracontractual" at the UN), but diverge in the case of "MC". For this term, the most commonly coincidental rendering is the false friend "tribunal de magistrados", but only in the WTO subset was it found in more documents than the other translations of "MC". The more generic rendering "tribunal de primera instancia" is more frequent in the UN, and the borrowing is more often accepted in EU translations to refer to court names of one of its Member States during the period covered.

\subsubsection{Distribution of Consistency and Accuracy}

In line with the overall variability averages, the most recurrent translation of "PFE" is found in the largest proportion of documents for this term compared to the most popular translations of the other two terms: $86.26 \%$ (EU), $62.90 \%$ (WTO) and 50\% (UN) of each subcorpus for "PFE", as opposed to $33.33 \%$ (EU), $20 \%$ (WTO) and $18.97 \%$ (UN) for "tort" and intermediate values of 50\% (EU and WTO) and $46.67 \%$ (UN) for "MC". In fact, the question of density or distribution of translation variants emerges as an important aspect to consider in the analysis of consistency. The same average degree of variability may be the result of divergent scenarios, for instance: one in which there is a clearly prevalent translation and other more marginal reformulations, and another where the number of translations is similar to the first scenario but their distribution is much more irregular.

By adding a diachronic dimension to the analysis of these scenarios, it is possible to explore potential patterns of convergence, consolidation or, inversely, sustained terminological dispersion. With this in mind, and to reduce the limitations of statistical analysis of patterns in small subcorpora, an intertextual variation rate ("InterVaR") was calculated by applying a multiplicative factor that increases for each translation variant according to the order of frequency (e.g. factor 1 for the occurrences of the most frequent translation, factor 2 for the second most recurrent reformulation, and so on, to produce a cumulative value that is then divided by the total number of occurrences of the source term). Therefore, the closer this rate is to 1 for a particular term, the closer its translations are to total consistency. With a view to offsetting the statistical weight of translations repeated within the same document, and thus refining the values associated with intertextual consistency, an adjusted variation of the same rate was also calculated by considering only one occurrence of each translation variant present in each document.

From a qualitative perspective, two further indicators are of utmost relevance to gain insights on the implications of consistency for institutional translation quality: intratextual consistency and, especially, translation accuracy levels. Both must be read in conjunction with intertextual consistency, as some degree of variation may be possible and 


\section{Fernando Prieto Ramos}

justified when several translations are acceptable and considered interchangeable for the same term. However, as mentioned in the introduction, intratextual consistency is particularly critical to ensure univocity in institutional translation, while translation inaccuracies are the most obvious obstacle to sound terminological harmonization and quality in scenarios where multiple translations of the same term coexist in a given setting.

The proportion of documents that include intratextual inconsistencies was calculated as a further step for a more qualitative examination of divergent translations. As regards the last indicator, i.e. translation accuracy, the following scale was applied to calculate the average accuracy rates ("AccuR") of all renderings of the terms in Spanish:

- Value 0: inaccurate translations that do not reflect the essential content of the original concept; they are too broad, divergent or misleading, or involve unjustified omissions (e.g. "a priori" for "PFE", "materia civil" for "tort" or "corte de los magistrados" for "MC").

- Value 1: acceptable translations considering the context, but not totally accurate (e.g. "elementos de prueba" for "PFE", "responsabilidad" for "tort" or "tribunal inferior" for "MC").

- Value 2: accurate translations that convey the essential content of the original concept and meet communicative adequacy requirements in context (e.g. "prueba prima facie" for "PFE", "(acto) ilícito civil" for "tort" or "tribunal de primera instancia (Magistrates' Court)").

In order to reduce any risk of subjective distortion, all the values assigned to translations were verified by two validators, paying particular attention to borderline cases. For four renderings, two different values were confirmed for various occurrences of the same translation depending on the context. As in the case of the InterVaR, AccuRs were calculated for each term, period and setting for the purpose of diachronic comparison. Likewise, a distinction was made between (a) AccuRs for the total amount of occurrences in absolute figures and (b) adjusted AccuRs excluding repeated occurrences of the same translation of a term within the same document. The calculation of averages per period involved using smaller fragmented subcorpora. This means that the values for certain terms and settings are statistically less insightful for the analysis of trends due to the low number of occurrences per period, namely, those for "tort" in WTO texts and "MC" in the EU corpus (see Table 7.1). In the latter case, averages could not be calculated for the period 2016-2019, as this included a single occurrence of the term.

The remaining absolute ("Abs.") and adjusted ("Adj.") AccuRs are provided in Table 7.3, where they are compared to the InterVaR values and the proportion of texts where intratextual inconsistencies ("IntraV.") were detected. The most remarkable commonality found 


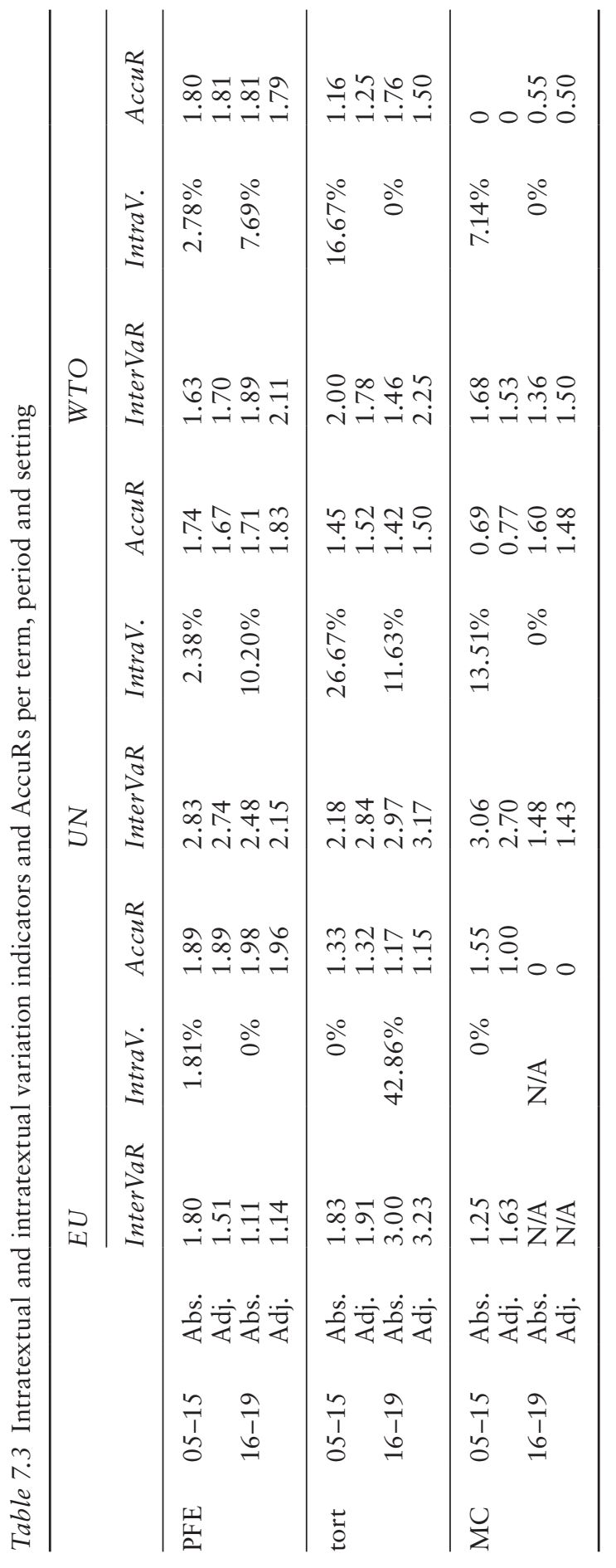




\section{Fernando Prieto Ramos}

is that, regardless of the internal variations in each subcorpus, AccuR levels systematically rank in the same order in all the periods and settings, and with strikingly similar adjusted average rates: "PFE", the less culture-bound term, has the best scores (between 1.67 and 1.96); it is followed by "tort" (between 1.15 and 1.52) and, finally, "MC" (between 0 and 1.48), which reflects the difficulty of dealing with legal asymmetry and the added risk of the misleading literal rendering "magistrado". Only in the 2016-2019 period and in a single setting, the UN, does the AccuR for this term exceeds 1 .

In terms of InterVaR, the most significant pattern in common is that "tort" registered the lowest intertextual consistency of the three terms in all periods and settings, per adjusted scores. These results align with the overall variability levels outlined in the previous section, as well as with the lower density of the most popular translations of "tort" per setting in comparison with those of "PFE" and "MC". "Tort" also concentrates the highest proportions of intratextual inconsistencies in a single period in all the organizations.

If we compare the three settings, as a general rule, the UN has the lowest consistency indicators, with InterVaR scores above 2, except for "MC" in the last period. It also registered the highest shares of intratextual variation in a single period for each term, with the exception of "tort". For this term, the highest InterVaR and the largest proportion of intratextual inconsistencies are found in the EU subcorpus for 2016-2019. These findings stand out, as the EU registered the lowest intertextual and intratextual variation scores for the other two terms. The results for "tort" reflect the fact that six out of 14 EU documents include several translations of the term, including up to five in one case and four in another.

Overall, the connection between consistency and accuracy is not straightforward, and no rule of thumb can be established from the comparison between terms and settings. For example, the highest accuracy rate in the EU corpus, that of translations of "PFE" in the second period (1.96), is coupled with the best adjusted InterVaR (1.14) of the series for this setting; however, if we observe the best accuracy results in the UN corpus, "PFE" translations also in the second period (1.83), they are less consistent (InterVaR of 2.15) than those of "MC" (InterVaR of 1.43 and AccuR of 1.48 in the same period). The unpredictable nature of internal terminological variations is also illustrated by examples of intratextual inconsistencies. For instance, none of the three translation variants for "PFE" found in the same UN text of 2008 ("indicios", "indicios razonables" and "indicios suficientes" in JIU/REP/2018/4) is inaccurate, while only one of the translations of "MC" in another UN text of 2005 ("juzgados de primera instancia", "Tribunales de Primera Instancia" and "Tribunal de Magistrados" in CERD/C/495/ADD.1) can be judged acceptable. 
However, the most systematic (and telling) finding in the parallel examination of consistency and accuracy derives from the analysis of inter-period variations. Changes in InterVaR and AccuR scores for each term and setting generally follow the same patterns: when intertextual variation is reduced, and therefore consistency improves, progress is also detected in terms of accuracy, and the same association is also the norm in the opposite direction. The most marked variation is that of translations of "MC" in UN texts between the first and the second period: the adjusted InterVaR drops by almost half (from 2.70 to 1.43 ) whereas the adjusted AccuR more than doubles (from 0.77 to 1.48). This trend suggests a process of terminological consolidation that is beneficial for quality and is worth exploring in more detail.

Several factors may contribute to this kind of process. They include the level of translation expertise (and specialized revision) devoted to specific terms and text types over time, as well as the level of coordination between translation professionals, especially when long texts are divided for translation. In institutional contexts, the impact of precedent must also be considered, particularly when it comes to repetitive text segments or literal quotations. Another related factor is the use of terminological resources for the terms under examination. We will focus on this particular aspect in the next section.

\subsection{The Potential Role of Institutional Resources}

It would be difficult (if not impossible) to determine, retrospectively, the extent to which the translation recommendations or interlinguistic associations made in ITRs played a more or less decisive role in each translation of legal terminology that has not been coined at international organizations. As pointed out in the introduction, internal termbanks are a mandatory source for the translation of institutional terminology and priority sources for all other terminology within each institution, even if professional translators tend to consult a diversity of resources as part of their research (see, e.g., Désilets et al. 2009). An indicator of the use of ITRs and their potential influence on terminological decision-making is, therefore, the degree of congruity between the renderings extracted from institutional texts and those recommended in ITRs. In turn, this correspondence can be considered indicative of the presumed adherence to such recommendations, even if the translation decisions are also supported by other sources, particularly previous translations in the same context.

For the analysis of congruity, the most relevant ITRs for the EnglishSpanish translation of institutional texts in each setting were considered, paying particular attention to the dates of creation and modification of the entries that apply to our selected terms. ${ }^{4}$ In the case of the EU, the main source is IATE as the terminology database of reference for all EU 
institutions and agencies. The contents of other EU institution-specific resources were merged into this massive collection in use since 2004. CuriaTerm, the internal database of the Court of Justice of the EU (CJEU), has migrated its contents into IATE until more recently, but with no impact on the records proposed for the terms under examination in this study. Given the predominance of EU documents on trade defense procedures in the analysis of "PFE" translations, the (internal) "Léxico antidumping y antisubvenciones" of 1997 (updated for the last time in 2009 and abbreviated hereinafter as "Léxico") was also considered. As noted by internal informants, this source, where "PFE" is translated as "indicios razonables," was conceived within the European Commission as a mandatory reference for the translation of texts on trade defense.

In the UN, the contents of databases from several bodies were gradually consolidated and integrated into UNTERM from 2013, and this termbank has been integrated into the UN's translation interface eLUNA in recent years. ITRs were previously more fragmented. One of the main databases before merging into UNTERM in 2015 was UNOGTerm, the database of the UN Office at Geneva (UNOG). It included a significant proportion of legal terminology, especially on human rights, which had been populated with a diversity of internal collections. Other popular internal glossaries still available for English-Spanish legal translation were also verified. One of them, the "Glosario provisional de términos jurídicos (E-S)" of 1996 (updated in 2003), ${ }^{5}$ includes two recommendations for "PFE" ("principio de prueba", "prueba prima facie") and three for "tort" ("acto ilícito civil", "ilícito civil extracontractual", "acto lesivo"), which are also integrated in UNTERM.

In the case of the WTO, two resources were considered: the WTO's dispute settlement glossary English-Spanish ("Términos y expresiones utilizados frecuentemente en el procedimiento de solución de diferencias", abbreviated as "DS Glossary"), which is the main source used by WTO translators for legal terminology, and WTOTERM, which works like a collection of trilingual glossaries. Both provide recommendations for "PFE": "prueba prima facie" (since 2002) and "prueba suficiente para justificar la presunción de un hecho" (from the General Agreement on Tariffs and Trade (GATT) glossary of 1988 integrated into WTOTERM), respectively.

We will not elaborate on the amount and reliability of information offered by each resource or entry. We will rather focus on the overall number and relevance of the translation recommendations they make for the three selected terms, and whether these recommendations are reflected in our corpus, particularly in the case of the most statistically significant corpus subsets: those of "PFE" in all settings and "MC" at the UN. Table 7.4 shows the share of occurrences (if any) that match each ITR recommendation available over the entire period covered by 
the corpus, ${ }^{6}$ as well as other ITR recommendations available during a more limited period.

"PFE" translations are, by far, the most consistent with ITRs. These results are in line with the InterVaR and AccuR values for each setting. The translation convention reflected in the European Commission's "Léxico" has prevailed in documents on EU trade defense measures. In only 14 or $5.75 \%$ of these documents (244 of the total of 262 EU corpus components for "PFE"), "indicios razonables" is not used in Spanish; inversely, alternative translations are found in 17 of the 18 documents that were not issued in connection with such trade defense measures. In fact, the EU's "PFE" subcorpus contains a significant number of repeated segments whose translations are systematically reproduced, thus greatly contributing to consistency scores (e.g. 63 of 67 slight variations of the segment "the applicant (has) provided (sufficient) prima facie evidence (showing) that" include "indicios razonables" in Spanish).

It must be noted, however, that the IATE recommendation for the most frequent translation was only introduced by the language services of the Council of the EU in October 2015 (February 2015 in the case of the other IATE renderings, i.e. long after the recommendation in the "Léxico"). It is presented as reliable (level 3 in a scale of 1 to 4 ) and refers to the UN's "Glosario provisional de términos jurídicos (E-S)" of 1996 as the source reference, rather than the European Commission's "Léxico" of 1997, and adds a note to indicate that "indicios razonables" in the plural is the most common rendering in trade defense instruments (antidumping and anti-subsidy regulations). ${ }^{7}$ Yet, these EU regulations refer to "pruebas" or "elementos de prueba" for "evidence" since Council Regulations (EC) Nos 384/96 and 2026/97 (in line with GATT 1994 provisions on the matter ${ }^{8}$ ), and "información que contenga a primera vista elementos de prueba" for "information showing prima facie evidence" in Council Regulations (EC) Nos 597/2009 and 1225/2009, and their latest amendments, Regulations (EU) 2016/1036 and 2016/1037 of the European Parliament and of the Council. The reformulation of "PFE" employed in these so-called "basic regulations" of 2016 (which are themselves included in our corpus) was only found in a judgment of the General Court (within the CJEU) of 9 September 2010 in connection with Regulation (EC) No 1225/2009 (Usha Martin Ltd v Council of the European Union and European Commission; Case T-119/06) and in Commission Implementing Regulation (EU) 2019/1948 of 25 November 2019 initiating an antidumping investigation.

The other two translations introduced in IATE in February 2015 as reliable options in a list of eight, "prueba de presunciones" and "prueba indiciaria", are functional renderings supported by Spanish case-law but not found among occurrences in EU translations in our corpus. Among the other three IATE suggestions for "PFE", only "presunción" was found in a document of 2005 , before the creation of the database entry. ${ }^{9}$ 
Table 7.4 Translation recommendations in ITRs and shares of corresponding corpus occurrences (where applicable)

\begin{tabular}{|c|c|c|c|}
\hline & $E U$ & $U N$ & WTO \\
\hline \multirow[t]{2}{*}{ PFE } & $\begin{array}{l}\text { Léxico: } \\
\text { indicio razonable } \\
\quad(84.42 \%)\end{array}$ & $\begin{array}{l}\text { UNTERM: } \\
\text { prueba prima facie }(44.96 \%) \\
\text { principio de prueba }(6.98 \%)\end{array}$ & $\begin{array}{l}\text { DS Glossary: } \\
\text { prueba prima facie } \\
\quad(69.83 \%)\end{array}$ \\
\hline & $\begin{array}{l}\text { IATE (since 2015): } \\
\text { indicio razonable } \\
\text { prueba indiciaria } \\
\text { prueba de } \\
\text { presunciones } \\
\text { prueba suficiente } \\
\text { para justificar la } \\
\text { presunción de un } \\
\text { hecho } \\
\text { prueba por presunción } \\
\text { prueba por } \\
\text { presunciones } \\
\text { presunción }\end{array}$ & $\begin{array}{l}\text { Second entry since } 2015 \text { : } \\
\text { prueba prima facie } \\
\text { prueba indiciaria }(0.78 \%) \\
\text { prueba de presunciones }\end{array}$ & $\begin{array}{l}\text { WTOTERM: } \\
\text { prueba suficiente } \\
\text { para justificar la } \\
\text { presunción de un } \\
\text { hecho }(2.59 \%)\end{array}$ \\
\hline Tort & - & $\begin{array}{l}\text { UNTERM: } \\
\text { responsabilidad } \\
\quad \text { extracontractual } \\
\quad(15.38 \%) \\
\text { acto ilícito }(10.99 \%) \\
\text { acto ilícito civil }(2.20 \%) \\
\text { daños y perjuicios }(2.20 \%) \\
\text { hecho ilícito } \\
\quad \text { extracontractual }(2.20 \%) \\
\text { acto lesivo } \\
\text { culpa civil } \\
\text { culpa extracontractual }\end{array}$ & - \\
\hline $\mathrm{MC}$ & $\begin{array}{l}\text { IATE: } \\
\text { juzgado de paz }\end{array}$ & $\begin{array}{l}\text { UNTERM: } \\
\text { justicia de paz } \\
\text { (only 2014-2018) }\end{array}$ & - \\
\hline
\end{tabular}

The UN and WTO results for "PFE" also show a marked difference between translation-ITR matches for the most frequent renderings and other translation options. The two UNTERM entries for this term (the second of which was created in August 2015) suggest "prueba prima facie" together with other options, of which only "principio de prueba" from the first entry (nine occurrences) and "prueba indiciaria" from the second (one occurrence in a document issued in November 2015) are found in our corpus. No thematic pattern or preference associated with a particular documental subset could be identified.

In the case of the WTO, the prevalence of "prima facie evidence" exemplifies the relevance of the organization's DS Glossary for the translation of legal terminology. Considering the direct connection between 
WTO and EU trade defense legal provisions and implementation mechanisms, it is interesting to note how translations of "PFE" in Spanish in these two settings diverge systematically, as opposed to the complete consistency of the original English term. In fact, some of the exceptions to the main rendering as "prueba prima facie" at the WTO result from reproducing the translation of the applicable EU "basic regulations" in EU notifications on antidumping or countervailing measures to the WTO. As a general rule, notifications and dispute settlement documents for these measures otherwise adhere to the prevalent translation. The other exceptions are found in: (a) a few trade policy review reports (including a diversity of renderings of marginal frequency), (b) in a series of report revisions on the accession of Liberia (a section on special border measures where a recurrent segment contains "pruebas de presunción" in Spanish) and (c) in documents that replicate "presunción" as used in one of the WTO agreements (article 58 of the Agreement on TradeRelated Aspects of Intellectual Property Rights).

The results on translation-ITR congruity for the other two terms are much more scattered, as translation suggestions are only found for "tort" in UNTERM and "magistrates' court" in IATE. The first of these databases contains five entries for "tort" in Spanish, four created at UNOG and one at the UN headquarters (with regard to three common areas, among others: law, international law and environment), totaling eight renderings of the term. Four of these translations, all correct in context, are found in the corpus but only represent $30.77 \%$ of occurrences. No correlations were observed between the contexts of use and translation choices. All UNTERM renderings refer to the same concept, as expressed in entry 64672, which is explicitly associated with "environmental law; based on the traditional theory of injury in common law." Coincidentally, the only two renderings included in more than one entry, "acto ilícito civil" and "culpa extracontractual", were found in one document (two occurrences) and in none, respectively. This is another sign of the high heterogeneity of translations of "tort".

Finally, "MC" is associated with "juzgado de paz" in two IATE entries on the basis of a translation from Spanish suggested by the CJEU's English Translation Division in 1994. This can only be considered a loose conceptual association, as the composition of MCs and the matters they deal with differ from those of juzgados de paz. The connection made in IATE for the translation into English is not reflected in the corpus. In practice, the borrowing of national court names of Member States prevails in CJEU documents. In our corpus, an example is found in a reference for a preliminary ruling. The other instances of borrowing are included in annexes to EU legal acts on judicial cooperation. However, the calque in Spanish was also used in a directive and two documents on policy implementation. It is not found in IATE, but it is used in the e-Justice webpages on national judicial systems translated by the 


\section{Fernando Prieto Ramos}

European Commission as "órganos jurisdiccionales de los magistrados" with reference to MCs in England and Wales, and "tribunales de magistrados" in the case of Northern Ireland. ${ }^{10}$

Interestingly, UNOGTerm entry 28240 also associated "MC" with "justicia de paz" (initially influenced by the French "justice de paix") and included a remark to refer to "juez de paz" between 2014 (in UNTERM since June 2015) and 2018. Since then, this entry does not include any rendering of the English term in Spanish, but only in French and Chinese. The reference to "justicia de paz" and "juez de paz" seems too peripheral and short-lived to have any significant impact, but corresponds to a conceptual association that was made more frequently in UN translations in the first period; "juzgado de paz" accounts for $19.35 \%$ of 62 occurrences in Spanish (12 instances in five documents) during that period, as opposed to only one in a total of 40 occurrences in 2016-2019. In the second period, occurrences of the borrowing (a translation technique generally avoided at the UN) were also rare (in two documents in 2016-2019 versus three in the first period, including an explanatory addition in one case in 2010), despite the new suggestion to borrow the original court name made in the internal "Orientaciones para la traducción de textos jurídicos (2015)". ${ }^{11}$ The trend to discontinue "juzgado de paz" runs parallel to the increase in the use of the more adequate formulation "tribunal de primera instancia", from $27.42 \%$ to $75 \%$ of occurrences, and to the decrease in the use of the calque "tribunal de magistrados", from $21.67 \%$ to $7.5 \%$ of occurrences. ${ }^{12}$ These patterns explain the accuracy levels provided in the previous section.

As also noted in the previous section, various factors may have shaped this process. The removal of the Spanish reference in the terminological entry for "MC" implies a deliberate action to reduce the risk of confusion and inaccuracy, but the gradual convergence toward "tribunal de primera instancia" (12 of 13 occurrences in 2019) is not reflected in UNTERM or in the internal recommendation of the borrowing issued as part of internal guidelines for legal translation in 2015. It would be necessary to consider other potential factors such as changes in profiles or working procedures, and more particularly whether the increasing use of "tribunal de primera instancia" results from deliberate terminology uniformization supported by automatic retrieval tools or other internal developments. ${ }^{13}$ It is apparent, however, that the main terminological database has been lagging behind in this process rather than serving as a reference.

\subsection{Conclusions}

The combined analyses of consistency and accuracy of translations and ITR recommendations for the three selected terms illustrate how 
concepts of more legal singularity or implying a higher degree of asymmetry with regard to the target-language legal traditions represent a challenge to terminological decision-making and quality in international institutional translation, and tend to be addressed in ITRs less systematically than other established institution-specific terminology. The less system-specific concept of "PFE" is the most frequently found and translated in a consistent and accurate manner in our corpus, and with the greatest correspondence to particular ITR recommendations.

More particularly, EU and WTO translations on antidumping and other trade defense measures show the weight of precedent and the relevance of internal thematic glossaries in ensuring terminological consistency in recurrent standardized institutional proceedings. The same patterns, however, also illustrate that, despite thematic homogeneity, the contents of different ITRs on certain terms are not always mutually consistent or in line with applicable legal provisions within the same setting or international legal instruments more broadly. In the case of "PFE", the prevailing target renderings, "indicios razonables" and "prueba prima facie", differ in closely related procedures in the EU and the WTO, respectively, even if the original term is identical. This also leads to a situation in which exceptions to the predominant translation in each context may derive from the reproduction of translation precedents from other settings (e.g. notifications of EU antidumping measures at the WTO). In other words, paradoxically, in order to preserve consistency, certain inconsistencies may have to be reproduced.

The high variability of "tort" translations (as evidenced by their intertextual and intratextual consistency scores, the lowest among the terms analyzed) and their globally acceptable accuracy levels point to a considerable number of valid synonyms in context. In turn, this may be related to the lack of a fully analogous legal concept in the targetlanguage legal systems and the fact that translators may reflect the main defining features of the original concept in several ways. This is also mirrored in the only database where the term appears, UNTERM, which encompasses several overlapping entries and translation variants for "tort" in Spanish. No clear associated thematic or contextual pattern was observed in UN translations, though. These results suggest that the proliferation of synonym translations in ITRs may contribute to preventing inaccuracies, but also to perpetuating terminological fragmentation rather than univocity, as in situations where ITRs provide no guidance on the term.

Finally, the most national system-specific term, "MC", seems to be as problematic for institutional terminologists as it is for translators. It concentrates the lowest accuracy scores in all the settings and periods, and it is the only term for which inaccurate renderings were identified in ITRs. 


\section{Fernando Prieto Ramos}

These findings are certainly explained by the difficulty of dealing with asymmetry between judicial systems and the associated risk of inaccuracy if previous expertise or comparative legal analysis is insufficient to detect key differences between bodies or the false friend "tribunal de magistrados". Nonetheless, translation variation is less marked than in the case of "tort", which suggests that higher inconsistency levels are not necessarily coupled with lower accuracy, as the nature and function of the term in each text may justify more or less tolerance to synonyms. The very idea of variation in denominations of a court name is at odds with translation adequacy since the communicative priority of identifying a judicial body in institutional texts conflicts with the idea of providing a diversity of names for it.

However, the findings of our diachronic analysis of translation patterns point to a clear correlation between changes in consistency and accuracy rates over time, albeit most often minor. The reduction of intertextual variation in the second period (2016-2019) generally coincides with an increase in translation accuracy for any given term and setting, and vice versa, which confirms the positive effects of terminological harmonization on both variables as indicators of translation quality. The most marked positive trend was found in the translation of "MC" at the UN, the organization that otherwise registered the highest variation rates for all terms.

For none of the three terms is there evidence of any major impact of ITR recommendations on translation decisions. Only the results for "PFE" in the EU and the WTO subcorpora can be considered highly indicative of adherence to the relevant glossaries. Yet, it is difficult to determine the extent to which ITRs are consulted and followed by translators in each instance. The most significant cases of terminological convergence identified are clearly influenced by translation precedents in each institution, while other aspects of decision-making fall beyond the scope of this study. As confirmed by the verification of ITRs, the legal terms analyzed, in particular the more system-specific, are not a priority for institutional terminology management and, consequently, ITR recommendations seem to play a peripheral rather than a central role in their translation. The inconsistencies and gaps detected in ITRs do not contribute to the effectiveness of these sources. Addressing them could crucially support new processes of terminological convergence and quality assurance, especially considering the functionalities of integrated online platforms for translation-oriented terminological work.

\section{Acknowledgments}

I would like to thank Diego Guzmán for his valuable assistance with data processing, as well as all institutional informants for their kind cooperation in the framework of the LETRINT project. 


\section{Notes}

1 Full results available at: https://es.surveymonkey.com/results/SM-X7FXFJXG/.

2 "Legal Translation in International Institutional Settings: Scope, Strategies and Quality Markers," led by the author and supported by the Swiss National Science Foundation through a Consolidator Grant.

3 Albeit originally inspired by Greek and Roman thought, and not always uniformly used in common law jurisdictions (see Herlitz 1994). For a comparison of prima facie standards in national and international jurisdictions, see Pfitzer and Sabune (2009). As they note, "civil law jurisdictions do have presumptions and the concept of prima facie proof; however, as in Germany, presumptions arise out of statutory provisions and concepts of prima facie evidence are used to rebut such presumptions" (ibid., 10).

4 The relevance and history of ITRs for our corpus analysis were doublechecked with institutional informants from each setting. However, it was impossible (and unnecessary for the purposes of the study) to track the origin and dates of all content changes of the relevant ITRs, particularly in the first period.

5 https://conf-dts1.unog.ch/1\%20SPA/Tradutek/Recursos\%20Juridicos/00 Glos\%20Juridico\%20Sureda.htm.

6 Unless otherwise specified, our inquiry led to the conclusion that all lexicographical contents included in Table 7.4 existed before the first year of our corpus, 2005, even if they were not necessarily integrated into online databases, where relevant, until later.

7 https://iate.europa.eu/entry/result/1094354/all.

8 Also in the pre-GATT-1994 Council Regulation (EEC) No 2423/88 of 11 July 1988 on protection against dumped or subsidized imports from countries not members of the European Economic Community.

9 This translation is given minimum reliability by IATE, as well as "prueba suficiente para justificar la presunción de un hecho." No references or reliability levels are provided in the entry for the remaining options, "prueba por presunciones" and "prueba por presunción” (as of April 2020).

10 These inaccuracies, first spotted in Prieto Ramos (2013), were still found, respectively, in the following overviews as of April 2020:

https://e-justice.europa.eu/content_judicial_systems_in_member_states16-ew-es.do? init=true\&member=1 (last update of 12 December 2016)

https://e-justice.europa.eu/content_ordinary_courts-18-ni-maximize MS-es.do?member=1 (last update of 28 August 2018).

11 https://conf.unog.ch/paginilla/wp-content/uploads/2015/05/Traducci\% C3\%B3n-de-textos-jur\%C3\%ADdicos-Orientaciones-2015.pdf.

12 No connection was found between translation decisions and references to specific national judicial systems in previous translations.

13 This translation was also suggested as an acceptable rendering in this kind of context in Prieto Ramos $(2013,99)$, when the problem of the misleading calque was highlighted.

\section{References}

Bazerman, Charles. 1994. "Systems of genres and the enactment of social intentions." In Genre and the New Rhetoric, edited by Aviva Freedman and Peter Medway, 79-101. London: Taylor \& Francis.

De Saint Robert, Marie-Josée. 2009. "Assessing quality in translation and terminology at the United Nations.” In CIUTI-Forum 2008 (Enhancing 
Translation Quality: Ways, Means, Methods), edited by Martin Forstner, Hannelore Lee-Jahnke and Peter A. Schmitt, 387-392. Bern, Berlin, Brussels, Frankfurt am Main, New York, Oxford, Vienna: Peter Lang.

Désilets, Alain, Christiane Melançon, Geneviève Patenaude, and Louise Brunette. 2009. "How translators use tools and resources to resolve translation problems: an ethnographic study." In Proceedings of the Workshop Beyond Translation Memories: New Tools for Translators, Machine Translation Summit XII. http://mt-archive.info/MTS-2009-Desilets-2.pdf.

ISO. 2015. ISO 17100. Translation Services - Requirements for Translation Services. Geneva: ISO.

Herlitz, Georg Nils. 1994. "The meaning of the term 'prima facie'." Louisiana Law Review 55 (2): 391-408.

Pfitzer, James Headen, and Sheila Sabune. 2009. "Burden of proof in WTO dispute settlement: Contemplating preponderance of the evidence." ICTSD Dispute Settlement and Legal Aspects of International Trade - Issue Paper No. 9. Geneva: ICTSD.

Prieto Ramos, Fernando. 2013. “¿Qué estrategias para qué traducción jurídica?: por una metodología integral para la práctica profesional." In Translating the Law. Theoretical and Methodological Issues/Traducir el Derecho. Cuestiones teóricas y metodológicas, edited by Icíar Alonso Araguás, Jesús Baigorri Jalón and Helen J. L. Campbell, 87-106. Granada: Comares.

Prieto Ramos, Fernando. 2014a. "International and supranational law in translation: From multilingual lawmaking to adjudication.” The Translator 20 (3): 313-331. doi:10.1080/13556509.2014.904080.

Prieto Ramos, Fernando. 2014b. "Parameters for problem-solving in legal translation: Implications for legal lexicography and institutional terminology management." In The Ashgate Handbook of Legal Translation, edited by Anne Wagner, King-Kui Sin and Le Cheng, 121-134. Farnham: Ashgate.

Prieto Ramos, Fernando, and Diego Guzmán. 2018. "Legal terminology consistency and adequacy as quality indicators in institutional translation: A mixed-method comparative study." In Institutional Translation for International Governance: Enhancing Quality in Multilingual Legal Communication, edited by Fernando Prieto Ramos, 81-101. Bloomsbury Advances in Translation. London: Bloomsbury. doi:10.5040/9781474292320.0015.

Robertson, Colin. 2015. "EU multilingual law: Interfaces of law, language and culture." In Language and Culture in EU Law. Multidisciplinary Perspectives, edited by Susan Šarčević, 33-51. Farnham: Ashgate.

Šarčević, Susan. 2010. “Creating a Pan-European Legal Language.” In Legal Discourse across Languages and Cultures, edited by Maurizio Gotti and Christopher Williams, 23-50. Oxford, Bern, Berlin, Brussels, Frankfurt am Main, New York, Vienna: Peter Lang.

Šarčević, Susan. 2013. "Multilingual lawmaking and legal (Un)certainty in the European Union.” International Journal of Law, Language \& Discourse 3 (1): 1-29.

Stefaniak, Karolina. 2017. "Terminology work in the European commission: Ensuring high-quality translation in a multilingual environment." In Quality Aspects in Institutional Translation, edited by Tomáš Svoboda, Łucja Biel and Krzysztof Łoboda, 109-121. Berlin: Language Science Press. doi:10.5281/ zenodo.1048192. 


\section{Annex: Translations of Selected Terms}

prima facie evidence

- indicio(s): indicio(s); _ razonable(s); _ suficiente(s); _ racionale(s); _ a primera vista; _ preliminares razonables; _ prima facie; _ probatorio.

- presunción(-ones): presunción(-ones); _ prima facie; _ salvo prueba de lo contrario (prima facie); suficiente _; elementos de _.

- prueba(s): prueba(s); _ prima facie; principio(s) de _; (elementos de _) a primera vista; _ suficiente(s); _ razonable(s); _ de presunción; _ que permitan concluir prima facie; _ que fundamenten / justifiquen la presunción; _ rebatible(s); elementos de _; _ a primera vista; constituir prima facie una _; _ iniciales; _ que así lo indican prima facie; salvo _ de lo contrario; _ verosímiles; _ indiciaria(s); _ presuntivas; _ concluyentes (prima facie); _ suficientes (prima facie).

- Other: demostrar prima facie; indicios o pruebas que fundamentan la presunción; documentación; acreditar prima facie; principios prima facie; revelar, prima facie; probatorio/a; evidencia a primera vista; a priori; elementos de juicio.

tort

- acto(s):_ilícito(s); _ ilícitos civiles; _ civil ilícito.

- agravio(s): agravio(s);_civil(es);_o responsabilidad civil extracontractual.

- delito(s): delito(s); _ civil(es).

- ilícito(s): ilícito(s); _ civil(es).

_ responsabilidad: responsabilidad; _ civil; _ extracontractual; _ delictual; _ civil de origen extracontractual; _ civil extracontractual; _ delictiva.

- Other: hecho ilícito; materia delictual; conducta delictual; delictual; daños; infracciones administrativas; infracción; extracontractual; infracción civil; materia civil; erróneamente; culpa extracontractual; daños de origen extracontractual; incumplimiento de contrato.

magistrates' court

- tribunal: tribunal; _ de primera instancia; de magistrados; _ inferior; _ ordinario; _ judicial; _ de Magistrados («Magistrates’ Court»); _ de los magistrados; _ de instrucción; _ de primera instancia (Magistrate's Court).

_ juzgado: juzgado; _ de paz; _ de primera instancia.

- Magistrate(sl'sls') Court: Magistrate(sl'sls') Court; _ (instancias judiciales competentes para el enjuiciamiento de causas penales y demandas civiles relacionadas con reclamaciones de menor cuantía).

- Other: corte de los magistrados; altos magistrados de los tribunales. 